Ethology, 71, 216-228 (1986)

(c) 1986 Paul Parey Scientific Publishers, Berlin and Hamburg

ISSN 0179-1613

Max-Planck-Institut für Verbaltensphysiologie, Seewiesen

\section{Avian Helpers at the Nest: Are they Psychologically Castrated?}

Hianz-Ulrich Reyler, John P. Ditrami \& Michael R. Hall

$$
\text { With one figure }
$$

Received: April 20, 198

Accepted: .May 22, 1985

\section{Abstract}

In cooperatively breeding pied kingfishers (Ceryle rudis) blood plasma levels of LH and testusterone (T) were compared among three types of males: breeders, primary (= relared) helpers and significantly lower T titers thern. These categories did not differ in LH, but primary helpers had small gonad sizes and no sperm production, sengesting thatp.r. The low levels were paralleled by eggs.

The differences in $T$ levels could neither be attributed to stochastic variation nor to differences in age, stress, molt, or reproductive activities. The most likely explanation arises from the observation The adaptive sis behaviorally dominated by breeders, whereas secondary helpers are not. discussed on the basis of empirical data and theoretical models. We a result from being dominated is pied kingfisher, and subordinate helpers in many other coope argue that primary helpers in the "unwillingly" suppressed in their sexual development; theoperative breeders, apparently are not when the costs from sexual competition with breedent; they rather "choose" delayed reproduction In contrast, helpers sat competition with breeders excecd the benefits from cooperative breeding. do, cannot be expected to show reduced fertility.

\section{Introduction}

Groups of cooperatively breeding vertebrates are characterized by social hierarchies. In some species such hierarchies lead to rank-related reproduction ("communal breeders": Vehrencamp 1977; MacDonald \& Moehlmann 1982 Mumme et al. 1983). In others, the result is usually the exclusive reproduction of a dominant pair aided by non-reproducing helpers-at-the-nest (WOOLFENDEN \& FITZPATRICK 1977; for reviews see BROWN 1978; EMLEN 1984). The absence of breeding in helpers could result from delayed maturity as helpers are normally younger than breeders, or from a direct inhibition through dominant group members. Such inhibition could be carried out on a behavioral level, in that subordinates are physically prohibited from copulating (mate-guarding) or, at a physiological level, so that the helpers are effectively unable to reproduce. This "psychological castration", as the latter usually is termed (e.g. BROWN 1978), couid be accomplished by inhibition of gonadal or pituitary/hypothalamic activity.

These possible explanations for the inhibition of reproduction were tested in the pied kingfisher (Ceryle rudis), which has two types of helpers: primary and secondary (REYER 1980). Both types consist of unmated surplus males and of mated males that do not breed. Primary helpers are offspring of the breeding pair from a previous year, whereas secondary helpers are not related to the breeders they join (REYER 1984). Primary helpers are with their parents throughout nestbuilding, copulation and egg-laying periods without the elicitation of mateguarding and aggressive behavior. In contrast, potential secondary helpers are not accepted before the young hatch and thereafter only when the parents' feeding capacities are limited (REYER 1984, 1986; REYER \& WESTERTERP 1985). The different treatment of primary and potential secondary helpers suggests that the two categories differentially threaten the breeding males' fitness through differential abilities of kleptogamy. This hypothesis was tested by investigating their reproductive statuses, as determined from plasma levels of the gonadotropin LH, and the gonadal steroid testosterone, with some additional information derived from gonad size and sperm production.

\section{Material and Methods}

Data were collected from two colonies of pied kingfishers in Kenya over a number of years (for details see REYFR 1980). Blood samples, taken from individually marked birds during the initial phases of nest-digging (April/May), were used to comparc lutcinizing hormone (LH) and testosterone plasma levels in three male categories: breeders (= mated males), primary helpers and secondary helpers. While the statuses of breeders and primary helpers were already apparent at this stage, status of potential secondary helpers had to be determined in retrospect, once they had been accepted after (hing.

Most blood samples were collected $3-5$ weeks before the first egg was laid (range 2-7 weeks). This ensured typical values for reproductive hormones during breeding. Birds were mistnetted or trapped between 6.30 and $10.00 \mathrm{~h}$. Due to varying field conditions, the time between catching a bird and bleeding it ("handling time") ranged from 10 to $310 \mathrm{~min}$. During this period the birds were kept in dark cloth bags. Blood samples of ca. 300ul were taken from the wing vein with capillary tubes which had been prerinsed with a solution of heparin in $5000 \mathrm{IU} / \mathrm{ml}$ and $\mathrm{NaN}_{3} 1 \mathrm{~g} / 1$ in distilled water. Samples were kept cool with ice cubes and centrifuged within one h for $20 \mathrm{~min}$. The plasma was then drawn off with a syringe and stored at $-28^{\circ} \mathrm{C}$ until assayed with standard radioimmunological techniques (for details see DITTAMI 1981).

In some birds, the endocrinological analysis was supplemented by laparotomy ( $\mathrm{n}=5$ males) or by collecting ejaculates ( $\mathrm{n}=15$ males) with a "milking" technique used in artificial insemination (THIEDE et al. 1981). The ejaculates were then diluted with physiological Ringer solution and immediately analysed for mobile sperm under a phase contrast microscope.

As a measure of a bird's phase in its annual reproductive cycle, molt was recorded for 10 primaries and 14 secondaries of the left wing using a code from $O$ (= old feather remaining) to 5 ( $=$ fully grown new feather) (DOUTHWAIT: 1971; GINN 1973). From the individual scores of the 24 feathers an average molt index 1 was cilculated for the whole wing. With this method, any average index 1 below 4.96 does not tell whether the bird is actually molting scveral feathers or whether he had 
interrupted molt for breeding, with one or more old feathers remaining. Therefore we used the number of wing feathers actually molting as an additional index 2 . To determine to what extent birds had been digging nest-holes (1. ecorded on a scale from $O(=$ no abrasion, tip of the beak pointed) to $2(=$ strong abrat rounded)

\section{Results}

\section{Hormone Plasma Titers}

In years with no rains the birds showed only week digging activity and never laid eggs. Hormonal data from such years have been eliminated from the following analysis. The endocrine levels from years in which breeding did occu are shown in Figure 1 for the various male categories. No difference in LH plasma titers between breeders, primary helpers and potential secondary helpers could be found (Fig. 1a). Testosterone concentrations, on the other hand, were much lower in primary helpers than in breeders and potential secondary helpers (Fig. 1 b). The latter two types of males did not differ.

Although primary helpers are usually younger than secondary helpers and breeders (REYER 1984) these differences in testosterone levels are not age related: when a few older primary helpers ( $\geq 2$ years) were compared with younger breeders and potential secondary helpers ( $=1$ year), the same differences were found (Fig. 1 c).

Other factors, which could have contributed to differences in testosterone plasma titers, include a) handling time before bleeding, as a measure of stres which in some species leads to a suppression of testosterone levels (SIEGEL 1980

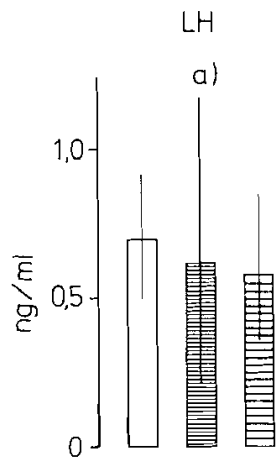

ก $46 \quad 11 \quad 24$

\section{TESTOSTERONE}

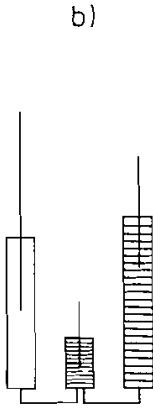

$46 \quad 11 \quad 29$

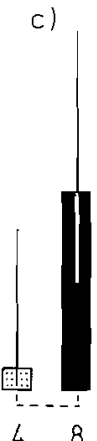

48
Fig. 1: Titers of LH (a) and testosterone (b) in breeders (white), primary helpers (narrow hatches) and secondary helpers (wide hatches). Means are shown with $95 \%$ confidence limits, calculated after log transformation of the original data and then retransformed and plotted on a linear scale. (c) Testosterone titers of primary helpers aged two years and more (dotted) and of yearling breeders and secondary helpers (black). Pooled data for Lake Victoria and Lake Naivasha for actual breeding seasons between 1979 and 1984. Numbers under the graphs give sample sizes. Bars are connected by horizontal lines if the difference between them is significant at $p<0.01(-)$ or $p<0.05(-)$ Mann-Whitney U test, two tailed
DitTam1 1981; Próve \& Sossinka 1982); b) stage of molt, as a measure of the phase in the annual reproductive cycle; c) nest digging, copulations and feeding of females, as measures of reproductive activities which can have a positive feedback on hormones (for summaries see BraIN 1977; LeSHNER 1978; SVARE 1983). To examine possible effects of these factors, we analysed whether or not the three male categories differed in any of them. Results are shown in Table 1.

a) Average handling times did not differ significantly between breeders, primary helpers and potential secondary helpers. It could be argued that despite this similar treatment - capture was more stressful for primary helpers than for the other two male categories, e.g. because of age differences. This, however, does not seem to be the case, as testosterone titers were not age-related (see above). Also, although there seemed to be a weak negative correlation between handling times and testosterone levels in the total sample $(\mathrm{p}=0.087)$, handling times were not significantly correlated with plasma levels of LH and testosterone within any of the three male categories (Table $1 \mathrm{a}$ ).

b) A negative relationship between times of molting and times of reproductive activities has been noted in most species of birds (PAYNE 1972). Indeed, the average molt index 1 of primary helpers was slightly lower than that of breeders, but it was not below that of potential secondary helpers which also had a lower index 1 than breeders (Table $1 \mathrm{~b}$ ). Molt index 2, the number of molting feathers per wing, was low for all males and not significantly different between any two of the three male categories (Table $1 \mathrm{c}$ )

c) During the early stages of nest-digging, when blood samples were taken, copulations were not observed in any of the birds. Feeding of females did occur occasionally, usually by their mates, less often by their primary helpers and rarely by potential secondary helpers. The latter were regularly prevented from feeding by the females' mates and primary helpers (REYER 1986). Nest digging is confined to breeders (REYER 1980). In the present study, this is reflected by beak condi-

Table 1: Handling time (a), molt indices ( $b, c)$ and beak abrasion (d) in breeders, primary helpers and secondary helpers as well as for all males combined (a). In (a), (c) and (d) the first number is the median, followed by the interquartile range in brackets. In (b) the numbers give means and standard deviations respectively. Also given in (a) are Spearman rank correlation coefficients between handling (c) and (d) are the same. Statistics as in Fig. 1

\begin{tabular}{|c|c|c|c|c|c|}
\hline & & Breeders & Prim. helpers & Sec. helpers & Combined \\
\hline \multirow{4}{*}{$\begin{array}{l}\text { a) Handling } \\
\text { time }\end{array}$} & $\tilde{x}$ & $55(40-150)$ & $75(35-171)$ & $83(45-128)$ & $70(45-160)$ \\
\hline & $r_{5} T$ & -0.206 & -0.086 & -0.069 & -0.278 \\
\hline & $\mathrm{r}_{\mathrm{sL}}$ & 0.028 & 0.457 & 0.250 & 0.181 \\
\hline & $\mathrm{n}$ & 19 & 6 & 14 & 39 \\
\hline b) Molt 1 & $x$ & $4.79( \pm 0.79)$ & $4.44( \pm 0.71)$ & $4.25( \pm 1.21)$ & \\
\hline c) Molt 2 & $\overline{\mathrm{x}}$ & $0(0-1)$ & $1(0-1)$ & $0(0-1)$ & \\
\hline \multirow[t]{2}{*}{ d) Beak } & $\tilde{x}$ & $2(1-2)$ & $0(0-0)$ & $0(0-1)$ & \\
\hline & $\mathrm{n}_{(b,-d)}$ & 46 & 13 & 28 & \\
\hline
\end{tabular}


tions: in breeders abrasion was much more pronounced than in primary and secondary helpers (Table 1d). The latter two categories showed very similar scores.

In summary: Some of the tested factors showed no difference between the three male categories (stress, molt index 2, absence of copulations). Where differences were found, they either separated male breeders from helpers (molt index 1, digging) or male breeders and primary helpers from potential secondary helpers (feeding of females). Thus, none of the parameters tested paralleled or could explain the observed testosterone differences. This does not rule out that two or more of these tested factors together may have generated the pattern. An analysis of such possible interactive effects on testosterone would have required calculation of partial correlations or multiple regressions. This was not possible because samples for the various parameters did not overlap completely.

\section{Hormones and Dominance}

The high testosterone levels in breeders and potential secondary helpers, as opposed to lower levels in primary helpers, are most clearly paralleled by dominance relationships. Throughout the year, primary helpers stay together with their parents in a stable group and are clearly subordinate to them. This is obvious from body postures and calls, the patterns and motivations of which will be described elsewhere (DUNN 1985; REYER \& DUNN 1985; REYer \& RISS, in prep.). In contrast, potential secondary helpers are less dominated. When trying to join various breeders (cP. Fig. 1 in REYER 1984), their displays and vocalizations are more aggressive than those of primary helpers and may cven lead to fights. Moreover, these encounters are much briefer and less frequent than those between breeders and primary helpers, and are interrupted by long periods during which the birds sit alone (REYER \& Riss, in prep.). Thus, in contrast to the situation with the accepted primary helpers, for the potential secondary helpers no stable dominance hierarchies seem to exist during the early stages of the breeding season when the blood samples were taken.

\section{Hormones and Fertility}

The low testosterone titers in primary helpers are interesting since this gonadal steroid is required for spermatogenesis in male birds (reviewed by FARNER \& FOLLETT 1979). In our study, titers as low as those of primary helpers (Fig. 1b) were paralleled by small gonad sizes and no sperm production. Five laparotomized males with an average testosterone titer of $0.20 \mathrm{ng} / \mathrm{ml}(95 \%$ confidence limits: $0.06-0.35$ ) had small gonads (mean diameter: $2.7 \mathrm{~mm}, 95 \%$ limits 2.0-3.4). Breeding kingfishers, on the other hand, can be expected to have gonadal sizes of $6-8 \mathrm{~mm}$ (average body weight of pied kingfishers: $77 \mathrm{~g}$ ).

With regard to the ejaculates, no sperm was detected in any of the samples which came from 15 birds with an average testosterone titer of $0.26 \mathrm{ng} / \mathrm{ml}(95 \%$ limits: $0.19-0.34$ ). Unfortunately all ejaculate samples were taken during a year when no breeding occurred and when even mated males and potential secondary helpers had low testosterone levels (mean: $0.17 \mathrm{ng} / \mathrm{ml} ; 95 \%$ limits: $0.13-0.21$;
$=30$. Consequently, no controls from birds with elevated titers are available. But, on a previous occasion, application of the same "milking" technique to three kingfishers which were courting (and thus very likely had elevated titers) did produce active sperm. Thus, the techrique can work in this species and should have produced sperm in birds with low testosterone levels if it had been there.

\section{Discussion}

None of the above comparisons between males of different status is as rigorous as it ideally should have been, and certain controls are lacking. This resulted from various adverse field conditions (e.g. failure of breeding seasons, spoiled blood samples due to power failure) which prevented us from getting data on hormone titers, gonad size and sperm production from the same individuals. Our results, however, are the first to show physiological differences between helpers and breeders in any cooperative bird socicty. Offering some tentative interpretations as to the causes and functions of these differences may therefore scrve to stimulate further investigations.

Possible Causes of Low Testosterone Levels and Reduced Fertility

The differences in testosterone titers among the three male categories could not be explained by differences in stress (Table $1 \mathrm{a}$ ), molt (Table $1 \mathrm{~b}, \mathrm{c}$ ), or reproductive activities such as digcring nest holes (Table $1 \mathrm{~d}$ ), feeding or copulating. Nor could the low testosterone titers in primary helpers be attributed to the birds' young age and "delayed maturity" (Fig. 1 b, c). Delayed maturity is often proposed to account for the absence of reproduction in helpers, and is even invoked as a cause for cooperative breeding (see KolinIs \& Prrilika 1981 for a critical discussion). Besides the fact that the gonadal status of helpers is only known in a few spccics (c.g. Dow 1978; ROWlly 1978; BROWN 1985), the explanation appears doubtful for various reasons: 1 . There are several species in which helpers may be as old as four or five years (BROWN 1985). 2. If circumstances are favourable, even yearlings can and do breed (e.g. ROWLEY 1965; StallCup \& WOOLFEnden 1978; EmLEn pers. comm.; this study). 3. Removal or loss of a dominant breeder can result in immediate assumption of that role by other, previously non-breeding birds in the unit (RowLEY 1965, 1981; BrowN 1978). 4. Birds that have bred before may switch back to become helpers (EMLEN 1981; Brown, in press).

One theoretically possible explanation for the endocrinological differences found in our study is that they merely reflect variations in the males' temporal patterns of hormone levels. Primary helpers may have quickly increased their titers later in the season, and the levels of breeders and potential secondary helpers at the time of sampling are also likely to change with time. In the absence of more precise data and for the sake of the following discussion, we assume that such changes would not affect the relative differences between the three male categories. 
Another possible cause for the observed differences is natural variation among individuals before the breeding season. Unmated males with levels below threshold for breeding might choose to become primary helpers and/or be accepted by breeders, whereas those with levels above threshold might choose to become secondary helpers and/or not be accepted as primary helpers. This interpretation is based on the "variance utilization" hypothesis developed by Brown (1978) and Brown \& Pimm (1985). Although we do not know when and how the differences in hormone levels appear, the explanation does not seem to hold for the pied kingfisher. Out of 24 primary helpers of known descent all but two assisted at least one of their parents, whereas out of 27 secondary helpers also living in their natal colony, all but four had no longer alive parents (Table 1 in REYER 1984). In the two exceptions among the primary helpers, the reasons for their association with unrelated breeders are unknown. The four exceptions among the secondary helpers were all sons of parents which did not breed in that particular year and/or already had one helper. These birds could not become primary helpers or only at a reduced benefit (REYER 1984). Thus, status as a primary or secondary helper seems to depend on whether breeding parents are present or not rather than on hormone titers. In other words, the difference in testosterone levels between the two helper categories appears to be a consequence, rather than a cause of the helpers' differential relationship with breeders (cp. "variance enhancement" hypothesis of BRown \& PIMm 1985). The most obvious difference lies in dominance relationships: primary helpers are dominated by the breeders with whom they permanently live in stable groups. Potential secondary helpers, on the other hand, had not yet been accepted when the blood samples were taken, were not clearly subordinate (REYER \& RISS, in prep.), and even occasionally fought with breeding males over the females. These diffcrcnces in aggressiveness, competition and stability of social relationships appear to be likely explanations for the testosterone differences between the three male categories. Similar correlations between levels of testosterone and intensity of competition have been found in other bird species (WINGFIELD 1984a, b, 1985, and literature therein).

Differences in testosterone levels, however, may also be relevant for the sexual behavior of the three male categories. The low testosterone levels of primary helpers correspond to non-breeding levels in other species (WINGFIELD \& Farner 1978a, b; Donham 1979; Lincoln et al. 1980; SCHWael et al. 1980; DitTami 1981, Silverin \& Wingfield 1982, Dawson 1983). The levels of breeders and potential secondary helpers are by the same standards elevated although peak values in breeders would not be expected until shortly before and during egglaying when most copulations occur. Combined with the results from laparatomy and sperm sampling, our hormone data suggest that, in contrast to active breeders and potential secondary helpers, primary helpers are not able to fertilize eggs. If confirmed, this could explain why primary helpers are tolerated through copulatory phases, whereas potential secondary helpers, probably physiologically capable of kleptogamy, are not (REYER 1984, 1986).

Surprisingly, the differences in testosterone levels between the three male categories were not paralleled by differences in gonadotropin titers (LH). As LH regulates gonadal development and secretion of testosterone (FARNER \& FOLLETT 1979), the two hormones usually show parallel fluctuations throughout the year (e.g. DiTTAMI \& REYER 1984). The causes for the temporal dissociation found in pied kingfishers, as well as in sparrows (Fig. 3 in WingFleLd et al. 1983; WiNGFIELD 1984 b), are not yet clear. However, insufficiently sensitive assays for LH and/or the episodic surges of LH secretion may have obscurcd differences between the groups (WINGFILLD 1984b). Also, if alternative ways of regulating testosterone secretion do exist (WINGHIELD 1984b), primary helpers could be inhibited on a gonadal rather than on a pituitary/hypothalamic level. In other words, the gonads may have been either turned off or prevented from developing although LH titers were comparable to breeders.

Low levels of sexual activity as a result of being dominated have been reported for a wide variety of vertebrate species, including some cooperative breeders (JaRvis 1981; ROOD 1980; VeHRENCAMP 1982; for reviews see MAC Donald \& Moehlmann 1982; Svare 1983; Wasser \& Barash 1983). Such situations are often described in terms like "psychological castration", "sexual suppression", or "reproductive despotism" (e.g. WASSER \& BARASH 1983). We fee that these terms are inappropriate as they confuse the behavioral and physiological level of analysis. The terms imply that the physiological reasons for the skewed reproduction are known. This is rarely the case. In some instances, a subordinate indeed may have undeveloped gonads, low androgen levels and no sperm production. This seems true for primary helpers in pied kingfishers. Alternatively, a helper may be in full reproductive state and attempt to copulate but be physically prevented by dominant group members (mate-guarding: MUmme et al. 1983; EMLIN \& Wrige 1986). As a third possibility, the behavior may be dependent on both hormone levels and context: e.g. a helper could maintain active gonads but only "use" them when the dominant male disappears and a breeding vacancy opens. Unless the physiological background is known, operational terms such as "reproductive delay" or "skewed reproduction" should only be used to describe the observed behavior.

\section{Possible Functions of Low 'Testosterone Levels and Reduced Fertility}

Even where the physiological mechanisms are known and reduced fertility has been proven, terms like "psychological castration", "sexual suppression", or "reproductive despotism" should be avoided as they seem to suggest that parents and other dominant group members can force subordinates not to develop active gonads. It is easy to perceive why dominant breeders should try to suppress sexual activity in subordinate helpers, at least to a certain extent (cp. models of Emlen 1982; Stacey 1982; Vehrencamp 1983; Brown \& Pimm 1985). It is difficult, however, to imagine why helpers should react to being dominated with reduced fertility, unless they benefit themselves. This idea is similar to one which WASSER \& BARASH (1983) have recently developed for female mammals. Their model states that individuals are able to maximize their own lifetime reproductive success by suppressing their reproduction until some future time, if future conditions can be expected to be so much better that the benefit from suppression 
exceeds the cost. The same model can be used to explain the blocking of pregnancy after conception ("Bruce effect") which occurs in many rodents when environmental conditions, both social and non-social, reduce expected benefits from present reproduction (e.g. ROHRBACH 1982).

Applied to pied kingfishers, the model would predict the ratio between future benefits and present costs to be better for primary than for secondary helpers. But the opposite is true. Due to lower survival rates and lower chances of obtaining a mate, primary helpers have a four times lower probability of becoming breeders than secondary helpers (REYER 1984). Thus, different cost/ benefit ratios in personal fitness do not suffice to account for the observed differences in reproductive condition between the two helper types; the effects on kin have to be considered as well.

A helper's attempt to copulate is likely to result in sexual competition and aggressive encounters within the cooperative group (cp. models by EMLEN 1982 and VEHRENCAMP 1983). For the helper this can have several negative effects, e.g. energetically demanding displays and fights, increased risk of injury and predation, expulsion from the group, waste of time and energy leading to suboptimal feeding of breeding females and/or young ("aggressive neglect", RIPLEY 1961), as well as attraction of predators to the nest and destruction of eggs and/or young through group members (VeHRenCamp 1977; Craig 1980; SHerman 1981; Trail e al. 1981; Mumme et al. 1983). Except for energy expenditure, risk of injury and predation, all other effects would impair primary more than secondary helpers. Until the age of two years, primary helpers gain about $80 \%$ of their inclusive fitness from investing in siblings. Secondary helpers, not closely related to the young they rear, gain only about $9 \%$ through this route and $91 \%$ through improving their own future reproductive success (REYER 1984). Consequently, primary helpers benefit more from accepting a subordinate position in a cooperative group.

In such a situation high testosterone titers, which can stimulate reproductive and aggressive behaviors (BRAIN 1977; LESHNER 1978; ADKINS-REGAN 1981; SVARE 1983; WINGFIELD 1984 b, c), would be selected against if competition jeopardized the beneficial group membership and/or is incompatible with feeding nestlings (cp. SiLVERIN 1980). They would also be selected against if low testosterone titer and inactive gonads were a cheaper way of improving inclusive fitness. Although cnergy requirements for testicular growth and sperm production seem to be negligible ( $\leq 1 \%$ of the basal metabolism; WALSBERG 1983), increased body weight through fully developed gonads may lead to increased energy expenditure, especially in a frequently flying and hovering bird like the pied kingfisher (cp. FREED 1981; NORBERG 1981). The costs of attaining and maintaining reproductive conditions are also indicated by our finding that in years when no breeding was possible even mated males and potential secondary helpers had low testosterone titers and small gonads (see Results 3 ). Further evidence comes from the numerous birds that regress their gonads and decrease their testosterone levels between breeding seasons. Moreover, ThApt.ryal. et al. (1983) have recently shown that high testosterone titers, in combination with certain levels of thyroxine, can markcdly increase oxygen consumption. Although all these possible energetic costs would hold for secondary helpers as well, they profit more and suffer less from competition than primary helpers do. Consequently, no reduction of their sexual and aggressive disposition and their concomitant testosterone levels would be expected.

In most cooperatively breeding vertebrates, helpers remain with the breeding pair (usually their parents) in a common territory throughout the year and benefit from group living in various ways (BROWN 1985). In their social status and their relatedness towards the young they rear they resemble more the dominated primary than the undominated secondary helpers. To what extent this also holds for their physiological state should depend on the ratio between the helpers' benefits from attaining sexual maturity (i.e. the chances of siring his own, surviving young) and the costs of sexual competition such as time and energy expenditure, personal risks to be injured or predated upon, and deleterious effects on survival of kin.

This ratio is expected to differ between species, populations, sexes and ageclasses. Species- and population specificity is indicated by those cooperative brceders which - in spite of dominance hierarchies - do show sexual competition (e.g. VEHRENCAMP 1977). Its intensity may vary between areas differing in the need of coopcration, the coefficients of relatedness between competing individuals or the probability of successful dispersal and independent breeding (Mumme et al. 1983; see also models by LMLEN 1982; STACEY 1982; VehrenCAmp 1983). The importance of gender is stressed by observations that reduction of fertility can differ between male and female subordinates (e.g. ANZENBERGER 1983). Also, in some species subordinates are inhibited through a parent of the opposite sex, in others through a parent of the same sex (KOENIG \& PITELKa 1979). The role of age for the cost/benefit ratio of reduced fertility has been demonstrated nicely in the cooperatively breeding cichlid fish Lamprologus brichardi. In this species being dominated leads to reduced growth rates in helpers (TABORSKY 1984). Their benefit from group living (= protection from predators) changes with body size. The size when helpers become sexually mature coincides with the size when their risk of being predated drops, i.e. when the costs of being expelled by cuckolded breeders decreases (TABORSKY 1985)

From the above discussion and our results on pied kingfishers we believe that for most species with dominance hierarchies the skew in reproduction may be better explained by the cost/benefit ratio of subordinates than by that of dominants. As to cooperative breeders, there is no evidence so far for helpers being "unwillingly" suppressed in their sexual development, nor is this to be expected on theoretical grounds (cp. VEHRENCAMP 1983). Rigorous empirical tests of these ideas are needed, but may be difficult to perform. They would require independent manipulation of the dominant's influence and the helper's cost/ benefit ratio. Experimental removal of dominants would not suffice as it changes both factors simultaneously. 


\section{Acknowledgements}

The study was supported with funds from the Max-Planck-Gesellschaft and granted by the Kenyan Government (Permit No. OP/13/001/C1891/14). S. and M. HIGGINs (Lake Naivasha) and the staff of the Kendu Bay Mission Hospital (Lake Victoria) kindly allowed use of their facilities for spinning and storing blood samples. Further, we are grateful to B. FOLLETT for the gift of LH antige and antisera, and to all who made useful comments on earlier drafts of the ms: E. ADKINS-REGAN, TABORSKY, P. WARD, W. WICKLER, J. C. WINGFiELD, and two anonymous referees. A. V ANDERSON (American Museum of Natural History), P. R. COLSON (British Museum of Natural History) and C VAN SOMEREN (National Museums of Kenya) kindly checked their bird collection for speinc $\mathrm{C}$. information was available.

\section{Literature Cited}

AdKINS-Regan, E., 1981: Hormone speciticity, androgen metabolism, and social behavior. Am. Zool. 21, 257-271.

ANZENBERGER, A. A., 1983: Bindungsmechanismen in Familiengruppen von Weißbüscheläffchen (Callitbrix jacchus). PhD. Thesis, Univ. Zürich.

Brain, F., 1977: Hormones and aggression. Ann. Res. Rev. 1, 1-126.

BROWN, J. L., 1978: Avian communal breeding systems. Ann. Rev. Ecol. Syst. 9, 123-155.

- , 1985: The evolution of helping behavior - an ontogenetic and comparative perspective. In The Comparative Development of Adaptive Skills: Evolutionary Implications. (Goluin, E. S., ed.) Lawrence Erlbaum Assoc. Publ., Hillsdale, London, pp. 137-171

- -, (in press): Cooperative breeding and the regulation of numbers. Proc. 18th Int. Orn. Congr. Moscow 1982

- - \& S. L. PIMM, 1985: The origin of helping: The role of variability in reproductive potential. J. theor. Biol. 112, 465-477.

CRAIG, J. L., 1980: Breeding success of a common gallinule. Behav. Ecol. Sociobiol. 6, 289-295. DAwsON, A., 1983: Plasma gonadal stcroids levels in wild starlings (Sturnus vulgaris) during the annual cycle and in relation to the stages of breeding. Gen. Comp. Endocrinol. 49, 286-294.

DitTAMI, J. P., 1981: Seasonal changes in the behavior and plasma titers of various hormones in barheaded geese. Z. Ticrpsychol. 55, 298-324.

- -, \& H.-U. REYER, 1984: A factor analysis of seasonal, behavioral, hormonal, and body weight changes in adult male barheaded geese, Anser indicus. Behaviour 90, 114 124

DONHAM, R. S., 1980: The annual cycle of plasma luteinizing hormone and sex hormones in male and female mallards (Anas platyrhynchos). Biol. Reprod. 21, 1273-1286.

DOUTHVArTE, R. J., 1971: Wing moult in the pied kingfisher, Ceryle rudis. Bull. Br. Orn. Club 91, $147-149$.

Dow, D. D., 1978: Breeding biology and development of the young of Manorina melanocephala, a communally breeding honeyeater. Emu 78, 207-222.

DunN, E. K., 1985: Ceryle rudis, pied kingfisher - social pattern and behaviour. In: Birds of Western Palaearctic. Vol. 4 (Cramp, S., ed.) Oxford Univ. Press, Oxford, pp. 726-728.

EMLi:eN, S. T., 1981: Altruism, kinship, and reciprocity in the white-fronted bee-catcr. In: Natural Selection and Social Behavior: Recent Research and New Theory. (AlEXAndeR, R. D., \& D. W. TinKLE, eds.) Chiron Press, New York, pp. 245-281.

--, 1982: The evolution of helping. II. The role of behavioral conflict. Am. Nat. 119, 40-53.

- - 1984: Cooperative breeding in birds and mammals. In: Behavioral Ecology an Evolutionary

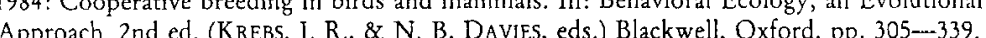
\& P. H. WREGE, 1986: Forced copulations and intra-specific parasitism: Two costs of social living in the white-fronted bee-eater. Ethology 71,2-29.

FARNER, D., \& B. FOLLETT, 1979: Reproductive periodicity in birds. In: Hormones and Evolution. (Barkington, E., ed.) Acad. Press, New York, pp. 829-872.

Finto. L. A 1981: Loss of mass in breeding wrens: Stress or adiptation? Ecology 62, 1179-1186. GINN, H. B., 1973: Moule recording. Auspicium 5 (Suppl.), 39-48.
JARVIS, J. U. M., 1981: Eusociality in mammals: Cooperative breeding in raked mole-rat colonies. Science 212, 571-573.

KolNiG, W. D., \& F. A. PITEE.KA, 1979: Relatedness and inbrecding avoidance counterploys in the communally nesting acorn woodpecker. Science 206, 1103-1105.

Ectorion in the evolution of cooperaive breeding in birds. In: Nacural Selection and Social Behavior: Recent Research and New Theory. (AIrYAN. DER, R. D., \& D. W. Tinkle, eds.) Chiron Press, New York, pp. 261-280

LESHNER, A. I, 1978: An Introduction to Behavioral Endocrinology. Oxford Univ. Press, Oxford. LINCOIN G. A P. A RACEY, P. J. SHARP, \& H KLANDORE, 1980: Endocrine changes assocised with spring and auturnn sexuality of the rook, Corous frugilegus. J. Zool. London 190 137-153.

MacDonald, D. W. \& P. MOehlimann, 1982: Cooperation, altruism and restraint in the reproduction of carnivores. In: Perspectives in Ethology. Vol. 5 (KLOPFer, P., \& P. BATESON, reproduction of carnivores. In: Perspectives in

Mumme, R. L., W. D. KoenjG, \& F. A. Prtelks, 1983: Reproductive competition in the acorn woodpecker: sisters destroy each other's eggs. Nature 306, 583-584.

NoRBERG, R. A., 1981: Temporary weight decrease in breeding birds may result in more fledged young. Am. Nat. 118, $838-850$

. Ant Avian Biology. Vol. 2. (FARNer, D. S., \& J. R. Krng, eds.) Acad. Press, New York, pp. 104-155.

PRÖE, E., \& R. SOSSINKA, 1982: Radioimmunoassay of plasma hormones and its use in investigations of hormone and behavior correlations in birds. In: Aspects of Avian Endocrinology Practical and Theoretical implications. (Scranes, C. G. et al., eds.) Grad Studies 26, Texas Tech. Press, Lubbock, pp. 97-103.

REYER, H.-U., 1980: Flexible helper structure as an ecological adaptation in the pied kingfisher (Ceryle rudis). Bchav. Ecol. Sociobiol. 6, 219-227.

- -, 1984: Investment and relatedness: A cost/benefit analysis of brecding and helping in the pied kingfisher (Ceryle rudis). Anim. Behav. 32, 1163-1178.

--, 1986: Breeder-helper-interactions in the pied kingfisher reflect the costs and benefits of cooperative breeding. Behaviour, in press.

- -, \& E. K. DUNN, 1985: Ceryle rudis, pied kingfisher - voice. In: Birds of Western Palaearctic Vol. 4. (Cramp, S., ed.) Oxford Univ. Press, Oxford, pp. 728-729.

- - \& K. WESTERTERP, 1985: Parental energy expenditure: A proximate cause for helper recruitment in the pied kingfisher (Ceryle rudis). Behav. Ecol. Sociobiol. 17, 363-369.

RIPLEY, S. D., 1961: Aggressive neglect as a factor in interspecific competition in birds. Auk. 78 $366-371$

RohrbacH, C., 1982: Investigation of the Bruce effect in the Mongolian gerbil (Meriones unguiculatus). J. Reprod. Fertil. 65, 411-417.

Rood, J. P., 1980: Mating relationships and breeding suppression in dwarf mongoose. Anim. Behav. 28, 143-150.

ROWLEY, I., 1965: The life history of the superb blue wren (Malurus cyaneus). Emu 64, 251-297.

- -, 1978: Communal activities among white-winged choughs Corcorax melanorhamphus. Ibis $120,178-197$.

- -, 1981: The communal life of the splendid wren, Malurus splendens. Z. Tierpsychol. 55 $228-267$.

SChWAbL, H. J., J. C. Wingelilu, \& D. S. FArNer, 1980: Seasonal variations in plasma levels of luteinizing hormone and steroid hormones in the European blackbird Turdus merula. Vogelwarte 30, 283-294.

SHERMAN, P. W., 1981: Reproductive competition and infanticide in Belding's ground squirrels and other animals. In: Natural Selection and Social Behavior: Recent Research and New Theory. (Alexander, R. D., \& D. W. Tinkle, eds.) Chiron Press, New York, pp. 311-331.

SIEGEL, H. S., 1980: Physiological stress in birds. BioScience 30, 529-534.

SiLvERIN, B., 1980: The effect of long acting testosterone treatment on free-living pied flycatchers, Ficedula hypoleura, diring the breeding period. Anim. Behay. 28, 906-912.

- - \& \& J. C. WINGFIEID, 1982: Patterns of breeding bchavior and plasma levels of hormones in free-living population of pied flycatchers, Ficedula bypolenca. J. Zool. 198, 117-129. 
STACEY, P. B., 1982: Female promiscuity and male reproductive success in social birds and mammals. Am. Nat. 120, 51-64.

StAllcup, J. A., \& G. E. WOOlFenden, 1978: Family status and contributions to breeding by Florida scrub jays. Anim. Behav. 26, 1144-1156.

SVARE, B. B., 1983: Hormones and Aggressive Behavior. Plenum Press, New York.

TABORSKY, M., 1984: Brood care helpers in the cichlid fish Lamprologus brichardi: their costs and benefits. Anim. Rehav. 32, 1236-1252.

- 1985: Breeder-helper conflict in a cichlid fish with brood-care helpers: an experimental analysis, Behaviour $95,45-75$

Thapliyal, J. P., P. Lal, A. K. Pati, \& B. B. Ph. GuptA, 1983: Thyroid and gonad in the oxidative metabolism, erythropoiesis, and light response of the migratory red-headed bunting Emberiza bruniceps. Gen. Comp. Endocrinol. 51, 444-453.

Thiede, H., D. GerRIETs, \& D. Berens von Rautenfeld, 1981: Zur Problematik und Technik der Samenübertragung beim Kleinvogel. Der prakt. Tierarzt 10, 879-882.

TrAIL, P. W., S. D. STRAHL, \& J. L. BROWN, 1981: Infanticide in relation to individual and flock histories in a communally breeding bird, the Mexican jay (Aphelocoma mexicana). Am. Nat. $118,72-82$.

VEHRENCAMP, S. L., 1977: Relative fecundity and parental effort in communally nesting anis. Science $197,403-405$.

- - 1982: Testicular regression in relation to incubation effort in a tropical cuckoo. Horm. Behav. $16,113-120$

_-, 1983: A model for the evolution of despotic versus egalitarian societies. Anim. Behav. 31, $667-682$.

WALSBERG, G. E., 1983: Avian ecological energetics. In: Avian Biology. Vol. 7. (FARNER, D. S., J. R. KING, \& K. C. Parkes, eds.) Acad. Press, New York, pp. 161-220.

WASSER, S. K., \& D. P. BARASH, 1983: Reproductive suppression among female mammals: Implications for biomedicine and sexual selection. Qu. Rev. Biol. 58, 513-538.

WiNGFIELD, J. C., 1984 a: Environmental and endocrine control of reproduction in the song sparrow Melospiza melodia. I. Temporal Organization of the breeding cycle. Gen. Comp. Endocrinol. $56,406-416$.

_- , 1984b: Environmental and endocrine control of reproduction in the song sparrow, Melospiza melodia. II. Agonistic interactions as environmental information stimulating secretion of testosterone. Gen. Comp. Endocrinol. 56, 417-424.

- $1984 \mathrm{c}$ : Androgens and mating systems: Testosterone-induced polygyny in normally monogamous birds. Auk 101, 665-671.

-_, 1985: Short term changes in plasma levels of hormones during establishment and defense of breeding territory in male song sparrows, Melospiza melodia. Horm. Behav. 19, 174- 187. , \& D. S. FARNER, 1978 a: The endocrinology of a naturally breeding population of the whitecrowned sparrow (Zonotrichia leucophrys pugetensis). Physiol. Zool. 51, 188-205.

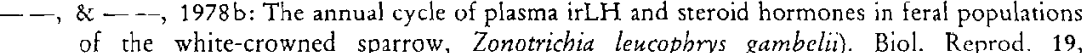
$1046-1056$.

-, M. C. MOORE, \& D. S. FARNER, 1983: Endocrine responses to inclement weather in naturall breeding populations of white-crowned sparrows (Zonotrichia leucopbrys pugetensis). Auk $100,56-62$.

WOOLFENDEN, G. E., \& J. W. FitzPatRICK, 1977: Dominance in the Florida scrub jay. Condor 79, $1-12$.

Authors' address: Dr, H.-U. ReYer, Dr. J. P. DitTAMI and Dr. M. R. HALL, Max-PlanckInstitut für Verhaltensphysiologie, D-8131 Seewiesen. 
later parental performance (Trivers, 1972; Halliday, 1978, 1983; Searcy, 1979). Support for this hypothesis is usually taken from courtship feeding (e.g. Nisbet, 1977; Tasker \& Mills, 1981), but I don't know of any study unambiguously proving that (a) good courtship feeders are more likely to be chosen by females than poor feeders, and (b) good courtship feeders are good parents. For pied kingfishers I do not have these data either. However, there is some indirect evidence for the role of feeding in mate choice.

(a) A secondary helper's attempt to associate with a female is more successful when fish are brought than when they are not (Table 1, row 5).

(b) Secondary helpers consistently feed females large cichlids (cp. narrow interquartile range in hatched bar of Fig. 1a). This makes the transferred food conspicuous and stereotyped. Both, conspicuousness and stereotypy are typical features of signals and increase the reliability of signal detection (WILEY, 1983).

(c) Secondary helpers, arriving with a fish in the colony, sometimes seem to delay feeding of the young until the female is present and can see them going into the nest (REYER, unpubl. data).

If, as indicated by these results, feeding is important in mate choice, secondary helpers should feed more to females and young where competition for females, and consequently the necessity to demonstrate their mate qualities, is higher. This is exactly what they did in groups with two or three helpers as opposed to groups with only one helper. Yet, even in the bigger groups, each helper seemed to take less food to the young than the male breeders did (Fig. 2). Why don't better feeders invade the system and outcompete male breeders and poorly feeding secondary helpers?

The success of a helper feeding many big fish over a helper feeding few small fish would depend (a) on the female's discriminating ability, and (b) on the relative fitness gained by males that contribute differentially.

(a) Discriminating abilities of females.

When seeing helpers near the nest, females can probably discriminate between males holding a big fish and males holding a small one, although this discrimination may not be perfect. Females should also be able to tell the difference between a slender Engraulicypris and a bulky cichlid.

A single fish, however, gives no reliable record of the total feeding contribution. Parents and primary helpers occasionally feed small fish as well (cf. wide interquartile range in black bar of Fig. 1a). Moverover, not all feedings occur in the presence of the female. Therefore, the frequency of 
feeding may be less easy to monitor by females than size and type of fish, and consequently feeding frequency offers the males more possibilities to deceive. It is interesting to note that differences between the feeding contributions of secondary helpers from big and small groups seem to be more pronounced in fish size and E/C-ratio than in number of fish (Fig. 2b-d).

Females could counteract such possible deceit by paying less attention to numbers than to size and type, i.e. by devaluating the fakeable signal (cf. WILEY, 1983). Alternatively, they could try to get a reliable record of the males' feeding frequencies by remaining near the nest and closely approaching birds returning with fish. Such behavior, however, would conflict with a female's own fishing activity. To what extent the resulting improvement in the helper's contribution and the inevitable decrease in her own contribution would affect a female's fitness remains speculation. The fact, however, that with increasing food demands of the young the females increasingly fish themselves rather than wait for helpers suggests that too fine a distinction between good and poor feeders may not pay.

(b) Relative fitness gain of good and poor feeders.

Even if the females' discrimination would favour good over poor feeders, the relative fitness gain of males pursuing these different tactics would not. In the following calculation $l_{H}$ is the probability for a poorly feeding secondary helper to survive into the next year, $1_{\mathrm{H}^{\prime}}$ that for a secondary helper feeding as much as parents and primary helpers do. Further, $\mathrm{m}_{\mathrm{H}}$ and $\mathrm{m}_{\mathrm{H}^{\prime}}$ are the corresponding chances of the surviving helpers to recruit mates, either from the helped females or from others. Poor feeders would be replaced by better feeders if $1_{\mathrm{H}}{ }^{\prime} \cdot \mathrm{m}_{\mathrm{H}}{ }^{\prime}>\mathrm{l}_{\mathrm{H}} \cdot \mathrm{m}_{\mathrm{H}}$. Under the present system $l_{\mathrm{H}}=0.74$ and $\mathrm{m}_{\mathrm{H}}=0.91$ (Table 3 , columns $5-7$ ). If mate choice would depend on feeding contributions alone, and thus the best among the surviving feeders would get a mating chance of $\mathrm{m}_{\mathrm{H}^{\prime}}{ }^{\prime}=1$, the above inequality would reduce to $l_{\mathrm{H}}{ }^{\prime}>0.67$. In other words, the better feeder must have a more than $67 \%$ chance of survival to succeed over the poor feeder. This is an unrealistic figure. Bringing more and bigger fish as well as a lower E/C-ratio to nestlings would mean a considerable increase in time and energy expenditure (REYER, 1984; REYER \& WESTERTERP, 1985). This is not only because the helpers could swallow fewer big, nutritious fish themselves; it is also because cichlids are more difficult to catch (Fig. 3a in REYER, 1984), and because big fish require more handling time (Douthwarte, 1971). As there is a significant 
negative correlation between energy expenditure and survival rate, feeding as much as parents and primary helpers would decrease the secondary helper's probability of survival $\left(l_{\mathrm{H}}{ }^{\prime}\right)$ to average values between 0.59 and 0.64 (see p. 289 and Table 3 in Reyer, 1984). This is less than the required limit of 0.67 . The discrepancy would be even bigger with mating chances of $\mathrm{m}_{\mathrm{H}^{\prime}}<1$ which would occur if, for whatever reason, the female preferred her old mate, whether or not the helper feeds as much or more.

Part of that discrepancy could be compensated for through kin benefits from the nestlings' increased survival and/or through increased direct benefits when these same young act as primary helpers next year if the former secondary helper gets to breed. Both benefits, however, are insignificant for secondary helpers, kin benefits mainly because of the helpers' low relatedness to the nestlings ( $r \leq 0.05)$, direct benefits mainly because of the low probability that the raised young will assist the secondary helper next year $(p=0.095, n=21)$. From the figures given in this paper and from previously published data on reproductive success in relation to number of helpers per pair (Table 6 in ReYer, 1984), it can be calculated that, under the present system, a secondary helper will reach an average inclusive fitness value of 0.97 genetic equivalents after two years (see formulas 2-3b in REYER, 1984), whereas a helper, feeding as much as parents, would only yield values between 0.82 and 0.95 . A helper, trying to feed more than parents, would even gain less. Thus, a higher feeding contribution and the concomitant increase in mortality would lead to a loss in fitness rather than to a gain.

In conclusion, all recorded interactions and food contributions of pied kingfisher breeders and helpers strongly support predictions from the cost/benefit ratios of giving and receiving help. In other cooperative breeders some costs and benefits for breeders and helpers may differ from those in pied kingfishers, but once they have been identified, it should be possible to detect behavioral signs of the breeder-helper-conflict in any species. As shown in this paper, these signs are not limited to overt aggression. They can find more subtle expressions (e.g. in feeding contributions to different group members) which are only discovered when several behavior patterns and interactions of breeders and helpers are quantified. Conversely, such quantifications, which are surprisingly rare in studies of cooperative breeding, can be a helpful tool for shedding light on the costs and benefits of giving and receiving help. This is especially true when the costs and benefits are confounded by numerous interacting demographic and ecological parameters (cf. Introduction). 


\section{Summary}

In most social species there is not only cooperation but also conflict between group members. Although various theoretical models have specified the conditions for, and the extent and direction of conflict and cooperation, there are few empirical data to test their predictions. This paper reports such a test for the pied kingfisher (Ceryle rudis), a cooperatively breeding bird species with two types of male helpers: primary (= related) and secondary ( $=$ unrelated).

In a breeding colony at Lake Victoria (Kenya), the birds were studied with regard to: (a) aggressive and non-aggressive interactions between breeders and helpers before and after chicks hatched; (b) frequency and effect of prey transfer from helpers to breeders; and (c) sizes and types of prey brought to females and nestlings. The six major results of the study and their explanations are as follows:

Result 1. Male breeders attack secondary male helpers more often than primary helpers (Table 1). Explanation: Because of a high male surplus, all helpers are also potential rivals, competing with male breeders for sexual access to the scarce females. Secondary helpers, however, impose higher costs and lower benefits on the male breeders' fitness than do primary helpers. This is because they provide less help, seem to be more capable of fertilizing eggs in the year of help, are more likely to displace breeders in subsequent years, and are more distantly related to breeders than are primary helpers.

Result 2. Primary helpers treat secondary helpers in the same way as male breeders do (Table 1). Explanation: Primary helpers are closely related to the young they raise. Therefore, any competition from secondary helpers that affects the breeder will decrease the primary helpers inclusive fitness.

Result 3. Female breeders tolerate secondary helpers more readily than do male breeders and primary helpers (Table 1). Explanation: Females do not incur the costs of male-male competition; indeed they even benefit from it, because (a) with additional males ( $=$ secondary helpers) they get a better food supply during egg formation than without them, and (b) secondary helpers lower the females' food contributions to nestlings more than those of male breeders and primary helpers.

Result 4. By offering fish, secondary helpers reduce the probability that they will be attacked by the breeding pair and any primary helpers (Table 1). Explanation: The helpers' food transfer is interpreted as a "payment" for being accepted as a group member. Receiving fish improves the breeders' and primary helpers' energy-budgets and their chances of fledging young and thus reduces the cost/benefit ratio of tolerating helpers. For females this holds already during egg formation, for males only after hatching, when the risk of kleptogamy is low, and when helpers can improve survival of the young.

Result 5. After the young have hatched, primary helpers carry more food to nestlings (= usually their sibs) than to females, whereas secondary helpers carry more to females than to unrelated nestlings (Table 2 and Fig. 1). Explanation: Primary helpers increase their inclusive fitness mainly through raising close kin, secondary helpers mainly through improving their chances of finding a mate and reproducing themselves.

Result 6 . In groups with two or three secondary helpers, each helper tends to provide the nestlings with more food than in groups with only one helper (Fig. 2). Explanation: Groups with two or three secondary helpers differ from groups with only one helper (a) in the breeders' average gain from each helper, and (b) in the extent of male-male competition for females as prospective mates. The helpers' higher food contribution to nestlings in bigger groups is interpreted (a) as a higher payment for being tolerated, and (b) as increased effort to signal their parental qualities to the females.

It is concluded that all behavioral interactions and food contributions closely reflect the costs and benefits of giving and receiving help, which vary with the sex of the breeder, the relatedness between the group members, and the period of the reproductive cycle. 


\section{References}

Balda, R. P. \& Balda, J. H. (1978). The care of young piñon jays (Gymnorhinus cyanocephalus) and their integration into the flock. - J. Ornithol. 119, p. 146-171.

Birkhead, T. R. (1979). Mate guarding in the magpie Pica pica. - Anim. Behav. 27, p. $866-874$.

Brown, J. L. (1972). Communal feeding of nestlings in Mexican jay (Aphelocoma ultramariana): Interflock comparison. - Anim. Behav. 20, p. 395-403.

- - (1974). Alternate routes to sociality in jays - with a theory for the evolution of altruism and communal breeding. - Am. Zool. 14, p. 63-80.

- (1978). Avian communal breeding systems. - Ann. Rev. Ecol. Syst. 9, p. $123-155$.

- - (1982). Optimal group size in territorial animals. - J. theor. Biol. 95, p. 793-810

- (1985). The evolution of helping - An ontogenetic and comparative perspective. In: The comparative development of adaptive skills: Evolutionary implications (E. Gollin, ed.), p. 137-171. Erbaum Associates, Inc. Publ., Hilldale, N.Y.

- \& Brown, E. R. (1980). Reciprocal aid-giving in a communal bird. - Z. Tierpsychol. 53, p. 313-324.

- - Dow, D. D., Brown, E. R. \& Brown, S. D. (1978). Effects of helpers on feeding nestlings in the grey-crowned babbler (Pomatostomus temporalis). - Behav. Ecol. Sociobiol. 4, p. 43-59.

Douthwaite, R. J. (1971). The treatment of fish by the pied kingfisher Ceryle rudis. Ibis 113 , p. $526-529$.

- (1973). Pied kingfisher Ceryle rudis populations. - Ostrich 44, p. 89-94.

Dow, D. D. (1977). Reproductive behavior of the noisy miner, a communally breeding honeyeater. - The Living Bird 16, p. 163-185.

- (1979). Agonistic and spacing behaviour of the noisy miner Manorina melanocephala, a communally breeding honeyeater. - Ibis 121, p. 423-436.

Drent, R. H. \& DaAn, S. (1980). The prudent parent: Energetic adjustment in avian breeding. - Ardea 68 , p. 225-252.

Dunn, E. K. (1985). Ceryle rudis, pied kingfisher - Social pattern and behaviour. In: Handbook of the birds of Europe, the Middle East and North Africa (S. Cramp, ed.), p. 726-728. Oxford University Press, Oxford.

EMLEN, S. T. (1978). The evolution of cooperative breeding in birds. - In: Behavioural ecology: An evolutionary approach (J. R. KREBS \& N. B. Davies, eds), p. 245-281. Blackwell, Oxford.

- - (1982a). The evolution of helping. I. An ecological constraints model. - Am. Nat. 119 , p. 29-39.

- - (1982b). The evolution of helping. II. The role of behavioral conflict. - Am. Nat. 119 , p. $40-53$.

- - (1984). Cooperative breeding in birds and mammals. - In: Behavioural ecology. An evolutionary approach, 2nd edition (J. R. KReBs \& N. B. Davies, eds), p. 305-339. Blackwell, Oxford.

- - \& Vehrencamp, S. L. (1983). Cooperative breeding strategies among birds. - In: Perspectives in ornithology (A. H. BRUsh \& G. A. ClLARK, Jr., eds), p. 93-120. Cambridge University Press, Cambridge.

- - \& WREGE, P. H. (1986). Forced copulations and intra-specific parasitism. Two costs of social living in the white-fronted bee-eater. $-Z$. Tierpsychol. (in press).

Gaston, A. J. (1978). The evolution of group territorial behavior and cooperative breeding. - Am. Nat. 112, p. 1091-1100.

Greenwood, P. J., Harvex, P. H. \& Perrins, C. M. (1978). Inbreeding and dispersal in the great tit. - Nature 271, p. 52-54.

Gladstone, D. E. (1979). Promiscuity in monogamous colonial birds. - Am. Nat. 114, p. $545-557$. 
Halliday, T. R. (1978). Sexual selection and mate choice. - In: Behavioural ecology. An evolutionary approach (J. R. KREBS \& N. B. Davies, eds), p. 180-213. Blackwell, Oxford.

- - (1983). The study of mate choice. - In: Mate choice (P. P. G. Bateson, ed.), p. 3-32. Cambridge University Press, Cambridge.

Hert, E. (1985). Individual recognition of helpers by breeders in Lamprologus brichardi (Cichlidae). - Z. Tierpsychol. 68, p. 313-325.

Hoogland, J. L. \& Sherman, P. W. (1976). Advantages and disadvantages of bank swallow (Riparia riparia) coloniality. - Ecol. Monogr. 46, p. 33-58.

Joste, N. E., Koenig, W. D., Mumme, R. L. \& Pitelka, F. A. (1982). Intragroup dynamics of a cooperative breeder. An analysis of reproductive roles in the acorn woodpecker. - Behav. Ecol. Sociobiol. 11, p. 195-201.

Koenic, W. D. \& Pitelka, F. A. (1981). Ecological factors and kin selection in the evolution of cooperative breeding in birds. - In: Natural selection and social behavior. Recent research and new theory (R. D. Alexander \& D. W. Tinkle, eds), p. 261-280. Ciron Press, New York.

Ligon, J. L. \& Ligon, S. H. (1978). Communal breeding in the green woodhoopoe as a case for reciprocity. - Nature 176, p. 496-498.

- - \& - (1983). Reciprocity in the green woodhoopoe (Phoeniculus purpureus). Anim. Behav. 31, p. 480-489.

Macdonald, D. W. \& Moehlman, P. D. (1982). Cooperation, altruism, and restraint in the reproduction of carnivores. - In: Perspectives in ethology, Vol. 5 (P. Klopfer \& P. Bateson, eds), p. 433-466. Plenum Press, New York.

Mumme, R. L., Koenic, W. D. \& Pitelka, F. A. (1983). Mate-guarding in the acorn woodpecker: within-group competition in a cooperative breeder. - Anim. Behav. 31, p. 1094-1106.

Nisber, I. C. T. (1977). Courtship feeding and clutch size in common terns, Sterna hirundo. - In: Evolutionary ecology (B. Stonehouse \& C. M. Perrins, eds), p. 101-109. Macmillan, London.

Power, H. W. \& Doner, C. G. P. (1980). Experiments on cuckoldry in the mountain bluebird. - Am. Nat. 116, p. 689-704.

Reyer, H.-U. (1980). Flexible helper structure as an ecological adaptation in the pied kingfisher, Ceryle rudis. - Behav. Ecol. Sociobiol. 6, p. 219-227.

- (1984). Investment and relatedness. A cost/benefit analysis of breeding and helping in the pied kingfisher (Ceryle rudis). - Anim. Behav. 32, p. 1163-1178.

-_- \& Dunn, E. K. (1985). Ceryle rudis, pied kingfisher-voice. - In: Handbook of the birds of Europe, the Middle East and North Africa (S. Gramp, ed.), p. 728-729. Oxford University Press, Oxford.

- -, Dittami, J. \& Hall, M. (1986). Avian helpers at the nest. Are they psychologically castrated? - Z. Tierpsychol. (in press).

- - \& Westerterp, K. (1985). Parental energy expenditure. A proximate cause for helper recruitment in the pied kingfisher. - Behav. Ecol. Sociobol. 17, p. 363-369.

Rowley, I. (1981). The communal life of the splendid wren, Malurus splendens. $-Z$. Tierpsychol. 55, p. 228-267.

SEARCY, W. A. (1979). Female choice of mates. A general model for birds and its application to red-winged blackbirds (Agelaius phoeniceus). - Am. Nat. 114, p. 77-100.

Sokal, R. R. \& Rohlf, F. J. (1969). Biometry. - Freeman, San Francisco.

Sonnenschein, E. \& Reyer, H.-U. (1983). Mate-guarding and other functions of antiphonal duets in the slate-coloured boubou (Laniarius funebris). - Z. Tierpsychol. 63, p. $112-140$.

Stacky, P. B. (1982). Female promiscuity and male reproductive success in social birds and mammals. - Am. Nat. 120, p. 51-64.

Stallcup, J. A. \& Woolfenden, G. E. (1978). Family status and feeding contributions to breeding by Florida scrub jays. - Anim. Behav. 26, p. 1144-1156. 
Sugg, M.St-J. (1974). Mensural and moult data from a breeding colony of pied kingfishers. - Ostrich 45, p. 227-234.

TABorskx, M. (1984). Broodcare helpers in the cichlid fish Lamprologus brichardi. Their costs and benefits. - Anim. Behav. 32, p. 1236-1252.

- (1985). Breeder-helper conflict in a cichlid fish with broodcare helpers. An experimental analysis. - Behaviour 95, p. 45-75.

- - \& Limberger, D. (1981). Helpers in fish. - Behav. Ecol. Sociobiol. 8, p. 143-145.

Tasker, C. R. \& Mills, J. A. (1981). A functional analysis of courtship-feeding in the red-billed gull, Larus novahollandiae scopulinus. - Behaviour 77, p. 222-241.

Trivers, R. L. (1972). Parental investment and sexual selection. - In: Sexual selection and the descent of man (B. CAmprell, ed.), p. 139-179. Aldine, Chicago.

Vehrencamp, S. L. (1979). The roles of individual, kin, and group selection in the evolution of sociality. - In: Handbook of behavioral neurobiology, Vol. 3 (P. Marler \& J. G. Vandendergh, eds), p. 351-394. Plenum Press, New York.

- (1983). A model for the evolution of despotic versus egalitarian societies. - Anim. Behav. 31, p. 667-682.

WILEY, H. (1983). The evolution of communication: Information and manipulation. In: Communication. Animal behaviour, Vol. 2 (T. R. Halliday \& P. J. B. Slater, eds), p. 156-189. Blackwell, Oxford.

Woolfenden, G. E. \& Fitzpatrick, J. W. (1977). Dominance in the Florida scrub jay. - Condor 79, p. 1-12.

- - \& - (1978). The inheritance of territory in group-breeding birds. - BioScience 28 , p. $104-108$.

\section{Zusammenfassung}

Bei den meisten sozial lebenden Tieren gibt es nicht nur Zusammenarbeit sondern auch Konflikt zwischen den Gruppenmitgliedern. Die Bedingungen für, sowie das Ausmaß und die Richtung von Konflikt und Zusammenarbeit sind in verschiedenen theoretischen Modellen dargelegt, aber selten empirisch getestet worden. Diese Arbeit beschreibt einen solchen Test für den Graufischer (Ceryle rudis), eine Vogelart mit kooperativer Jungenaufzucht und zwei Typen von männlichen Helfern: primären (= verwandten) und sekundären (= nicht verwandten).

In einer Brutkolonie am Viktoriasee in Kenya wurden folgende Parameter gemessen: (a) aggressive und nicht-aggressive Interaktionen zwischen Brutvögeln und Helfern, vor und nach dem Schlüpfen der Jungen; (b) Häufigkeit und Auswirkungen von Fischübergabe zwischen Helfern und Brutvögeln; und (c) Größe und Art der Fische, mit denen Weibchen und Nestlinge gefüttert werden. Die sechs wesentlichen Ergebnisse der Untersuchung und ihre Erklärungen sind folgende:

Ergebnis 1. Brutmännchen greifen sekundäre Helfer häufiger an als primäre Helfer (Tabelle 1). Erklärung: Wegen eines hohen Männchen-Überschusses sind alle Helfer auch potentielle Rivalen, die mit den Brutmännchen um die Weibchen konkurrieren. Sekundäre Helfer bedeuten jedoch ein größeres Risiko und einen geringeren Gewinn für die Fitness der Brutmännchen als primäre Helfer. Das liegt daran, daß sekundäre Helfer die Jungen weniger füttern als primare Helfer, mit den Brutvögeln weniger verwandt sind und eher in der Lage sind mit den Weibchen zu kopulieren oder sie sogar in folgenden Jahren ganz zu übernehmen.

Ergebnis 2. Primäre Helfer behandeln sekundäre Helfer in der gleichen Weise wie Brutmännchen das tun (Tabelle 1). Erklärung: Primäre Helfer sind mit den Brutmännchen und den Jungen, die sie aufziehen, eng verwandt. Jede Konkurrenz durch sekundäre Helfer, welche die Fitness der Brutmännchen verringert, beeinträchtigt daher auch die Gesamtfitness der primären Helfer. 
Ergebnis 3. Brutweibchen dulden sekundäre Helfer bereitwilliger als Brutmännchen und primäre Helfer das tun (Tabelle 1). Erklärung: Weibchen haben mehr Vor- als Nachteile von der Konkurrenz zwischen Männchen, weil zusätzliche Männchen (= sekundäre Helfer) ihnen (a) während der Eierproduktion eine bessere Nahrungsversorgung verschaffen und (b) nach dem Schlüpfen der Jungen die Fütterungen der Weibchen an die Nestlinge in stärkerem Maße verringern als die von Brutmännchen und primären Helfern.

Ergebnis 4. Durch die Übergabe von Fischen verringern sekundäre Helfer die Wahrscheinlichkeit, daß sie von Brutvögeln und primären Helfern angegriffen werden (Tabelle 1). Erklärung: Die Übergabe von Fischen wird als "Bezahlung" gedeutet, die der sekundäre Helfer leisten muß, um als Gruppenmitglied aufgenommen zu werden. Die Versorgung mit Fischen verbessert den Energiehaushalt und den Bruterfolg der anderen Gruppenmitglieder und verringert damit ihre Kosten/Nutzen Bilanz, die aus der Duldung des sekundären Helfers entsteht. Für Weibchen gilt das bereits vor den Eiablage, für Männchen erst nach dem Schlüpfen der Jungen, wenn das Risiko von Kleptogamie gering ist und der Helfer die Überlebenschancen der Jungen verbessern kann.

Ergebnis 5. Nach dem Schlüpfen der Jungen füttern primäre Helfer die Nestlinge (=meistens ihre Geschwister) mehr als die Weibchen, während sekundäre Helfer die Weibchen mehr füttern als die nicht verwandten Jungen (Tabelle 2 and Abb. 1). Erklärung: Primäre Helfer verbessern ihre Gesamtfitness vor allem durch die Aufzucht von nahen Verwandten, sekundäre Helfer vor allem durch eine Steigerung ihrer Verpaarungschancen und damit ihres eigenen künftigen Fortpflanzungserfolges.

Ergebnis 6. In Gruppen mit zwei oder drei sekundären Helfern versorgt jeder Helfer die Jungen mit mehr Nahrung als in Gruppen mit nur einem Helfer (Abb. 2). Erklärung: Gruppen mit zwei oder drei Helfern unterscheiden sich von Gruppen mit nur einem Helfer (a) im durchschnittlichen Nutzen, den die Brutvögel von jedem Helfer haben und (b) im Ausmaß, in dem Männchen um Weibchen konkurrieren. Der höhere Beitrag, den Helfer in größeren Gruppen leisten, wird gedeutet (a) als höhere "Bezahlung", um geduldet zu werden und (b) als verstärkte Anstrengung der Helfer, den Weibchen ihre Qualität als künftige Partner zu signalisieren.

Die Untersuchung zeigt, daß bei Graufischern das Verhalten von Brutvögeln und Helfern die Nutzen und Kosten der kooperativen Jungenaufzucht widerspiegelt, und zwar in Abhängigkeit vom Geschlecht des Brutvogels, dem Verwandschaftsgrad zwischen den Gruppenmitgliedern und dem Zeitpunkt im Brutzyklus. 